\title{
Development and application of a processing model for the Irish dairy industry
}

\author{
U. Geary, ${ }^{* 1}$ N. Lopez-Villalobos, $†$ D. J. Garrick, $†$ and L. Shalloo* \\ *Livestock Systems Research Department, Animal and Grassland Research and Innovation Centre, Teagasc, Moorepark, Fermoy, Co. Cork, \\ Ireland \\ †Institute of Veterinary, Animal and Biomedical Science, Massey University, Palmerston North 4442, New Zealand
}

\section{ABSTRACT}

A processing-sector model was developed that simulates (i) milk collection, (ii) standardization, and (iii) product manufacture. The model estimates the product yield, net milk value, and component values of milk based on milk quantity, composition, product portfolio, and product values. Product specifications of cheese, butter, skim and whole milk powders, liquid milk, and casein are met through milk separation followed by reconstitution in appropriate proportions. Excess cream or skim milk are used in other product manufacture. Volume-related costs, including milk collection, standardization, and processing costs, and product-related costs, including processing costs per tonne, packaging, storage, distribution, and marketing, are quantified. Operating costs, incurred irrespective of milk received and processing activities, are included in the model on a fixed-rate basis. The net milk value is estimated as sale value less total costs. The component values of fat and protein were estimated from net milk value using the marginal rate of technical substitution. Two product portfolio scenarios were examined: scenario 1 was representative of the Irish product mix in 2000, in which $27,39,13$, and $21 \%$ of the milk pool was processed into cheese $(€ 3,291.33 / \mathrm{t})$, butter $(€ 2,766.33 / \mathrm{t})$, whole milk powder $(€ 2,453.33 / \mathrm{t})$, and skim milk powder $(€ 2,017.00 / \mathrm{t})$, respectively, and scenario 2 was representative of the 2008 product mix, in which $43,30,14$, and $13 \%$ was processed into cheese, butter, whole milk powder, and skim milk powder, respectively, and sold at the same market prices. Within both scenarios 3 milk compositions were considered, which were representative of (i) typical Irish Holstein-Friesian, (ii) Jersey, and (iii) the New Zealand strain of Holstein-Friesian, each of which had differing milk constituents. The effect each milk composition had on product yield, processing costs, total revenue, component values of milk, and the

Received May 28, 2010.

Accepted August 5, 2010.

${ }^{1}$ Corresponding author: una.geary@teagasc.ie net value of milk was examined. The value per liter of milk in scenario 1 was $24.8,30.8$, and 27.4 cents for Irish Holstein-Friesian, Jersey, and New Zealand strain of Holstein-Friesian milk, respectively. In scenario 2 the value per liter of milk was 26.1, 32.6, and 28.9 cents for Irish Holstein-Friesian, Jersey, and New Zealand strain of Holstein-Friesian milk, respectively.

Key words: dairy, processing sector, model, milk pricing

\section{INTRODUCTION}

International dairy markets are experiencing considerable change as they find a new equilibrium postrecession, recovering from low milk prices and high feed costs and as the effect of deregulation in the European Union, in terms of Common Agricultural Policy, takes its toll. Over the last 25 years, with milk quotas in place, not only have European Union markets gained stability through price support, but international markets have also benefited due to strategic product management on the world market. However, as the European Union milk quota increases annually by $1 \%$, with its ultimate removal in 2015, world dairy market fluctuations and price volatility will be a constant challenge to the future dairy industry. Milk processors who can react to fluctuating markets will achieve greater return for the milk that is produced (Van Der Pool, 2007), thus ensuring their sustainability. A model capable of informing strategic decisions and milk pricing strategies would be instrumental in determining the optimum product portfolio and milk supply profile.

Various milk-processing-sector models have been developed around the world. A cost model was developed by Krell and Wietbrauk (1993) for the production of Gouda cheese. A model developed by Bangstra et al. (1988) was used to estimate the value of milk based on the manufacture of fluid milk, cheese, butter, and nonfat dried milk. A comprehensive model was developed by Garrick and Lopez-Villalobos (2000), which modeled the production of fluid milk, butter, cheese, casein, whole milk powder (WMP), skim milk powder 
(SMP), whey powder, and buttermilk powder (BMP) from milk within the context of the New Zealand dairy industry. Burke (2006) developed a model to simulate cheese manufacture with the aim of minimizing production costs. These models were all developed to simulate the processing of milk into specific dairy products. The quantity and costs associated with product manufacture were estimated by simulating the manufacturing process. Therefore, the value of milk could be determined based on the quantity and value of product produced less the processing costs associated with processing that milk, which should then be reflected in the milk payment system.

The primary objective of a milk pricing system is to ensure that the price paid to producers reflects as accurately as possible the amount and value of products that can be produced from that milk, less the transport, processing, and other ingredient costs incurred (Emmons et al., 1990). Milk pricing is one of the only methods of communication between the milk processor and the producer (Wallace et al., 2002) with the aim of increasing the overall efficiency of the dairy industry. Multiple-component pricing (MCP) of milk is defined as the pricing of milk on the basis of more than one component, such as fat and protein; fat and SNF; or fat, protein, lactose, and minerals (Emmons et al., 1990). Researchers have developed many MCP systems over the years (Emmons et al., 1990; Garrick and Lopez-Villalobos, 2000; Wallace et al., 2002), each using different milk pricing methodologies.

The objective of this paper was to describe and evaluate a milk-processing-sector model. The model was evaluated across milk with varying composition within 2 product portfolio scenarios at the same market prices. The first and second scenarios examined the Irish dairy industry product portfolio in 2000 and 2008, respectively, to estimate the effect each had on the yield of products, processing costs, product sale value, component values of milk, and the net value of milk. Across both scenarios the effect of variation in milk composition from 3 differing animal types was evaluated.

\section{MATERIALS AND METHODS}

\section{Model Description}

A mass balance processing-sector model that accounts for all inputs, outputs, and losses involved in dairy processing was developed. The model is a mathematical representation of the process of conversion of milk into dairy products (Figure 1). Within the model the production of each of the dairy products is simulated (cheese, butter, WMP, SMP, fluid milk, and casein). The key model inputs of volume and composition of milk intake and product portfolio and its composition are used in the simulations. The quantities of products and by-products that can be produced from the available milk pool are calculated. Processing costs are simulated, and the return from raw milk and its individual component values are calculated.

\section{Dairy Product Production}

The proportion of milk used in the production of each product is an input. A proportion of the milk pool is separated into cream and skim milk; the proportion destined for separation is determined by the composition of (a) the milk and (b) the final product to be manufactured (Table 1). The volumes of whole milk, cream, and skim milk from separation are reconstituted in differing proportions to meet final product specifications. Excess cream not used in the production process can be sold off or go on to butter manufacture, with excess skim milk remaining from butter manufacture being used in the production of SMP. Because this is a mass balance model, all components of the milk received are accounted for, whether they are used in product manufacture or lost in the production process. The simulation for each of the dairy products produced in the model is described in detail below.

Cheese. Van Slyke and Price (1949) developed a cheese yield equation that is the industry norm today:

$$
\mathrm{Y}=\left[\left(0.93 \mathrm{X}+0.78 \mathrm{X}_{\mathrm{P}}-0.1\right) \times 1.09\right] /(1-\mathrm{W})
$$

where $\mathrm{Y}=$ yield of cheese, $\mathrm{X}=$ percentage fat in the milk, $\mathrm{X}_{\mathrm{P}}=$ percentage protein in the milk, and $\mathrm{W}=$ water content of the cheese. Milk protein is made up of casein and whey. The casein proportion goes toward curd formation, and the whey proportion leaves the cheese process in a liquid form. Cheese protein is calculated from the ratio of milk protein in the cheese yield $\left(X_{P} / Y\right.$ from Van Slyke) multiplied by the casein proportion of the protein (0.8), the efficiency of casein utilization (0.99), and an adjustment for noncasein protein in the cheese $(1 / 0.98)$ :

$$
\begin{aligned}
\text { cheese protein } & =\left\{\left[\left(\mathrm{X}_{\mathrm{P}} / \mathrm{Y}\right) \times\left(\operatorname{casein} / \mathrm{X}_{\mathrm{P}}\right)\right]\right. \\
& \times 99 \%\} / 98 \%
\end{aligned}
$$

The cheese yield is calculated by dividing the volume of cheese protein by the required protein content of the final cheese product, taken to be $24.5 \%$ in this analysis (Table 1).

The whey by-product from cheese production is manufactured into whey powder. The volume of whey 
Table 1. Composition of dairy products simulated in the model ${ }^{1}$

\begin{tabular}{lrrrrrr}
\hline Item & Cheese & Butter & WMP & SMP & Whey & BMP \\
\hline Fat, \% & 35.00 & 84.00 & 26.50 & 1.00 & 1.00 & 8.30 \\
Protein, \% & 24.50 & 0.59 & 25.10 & 33.00 & 15.15 & 41.72 \\
Lactose, \% & 1.39 & 0.79 & 39.80 & 54.00 & 77.15 & 40.32 \\
Minerals, \% & 2.15 & 0.12 & 5.90 & 8.00 & 4.32 & 4.66 \\
Water, \% & 35.26 & 14.50 & 2.70 & 4.00 & 2.38 & 5.00 \\
\hline
\end{tabular}

${ }^{1} \mathrm{WMP}=$ whole milk powder; $\mathrm{SMP}=$ skim milk powder; $\mathrm{BMP}=$ buttermilk powder.

produced is calculated by subtracting the volume of cheese produced from the volume of milk to cheese less any calculated losses. The whey milk is evaporated to a water content of $48 \%$ and then dried to a water content of $2.38 \%$ to produce whey powder. Cream left over from separation is used in the manufacture of butter.

Butter. Cream from separation and surplus from the production of other products (cheese, WMP, SMP, and fluid milk) is used in butter manufacture. The volume of butter that can be produced from this cream is calculated by dividing the volume of fat in cream by the required fat content in the final butter product, taken to be $84 \%$ (Table 1). A by-product of butter manufacture is buttermilk, which is manufactured into BMP by evaporating to $50 \%$ water content and then drying to $5 \%$ moisture content.

WMP and $\boldsymbol{S M P}$. For WMP the standardized milk is evaporated to a moisture content of $48 \%$ and then dried to a $2.7 \%$ moisture content, holding fat, protein, lactose, and minerals constant. For SMP the standardized milk is evaporated to a moisture content of $48 \%$ and dried to a moisture content of $4 \%$, holding fat, protein, lactose, and minerals constant.

The model is capable of simulating the production of each of these products. However, in this analysis cheese, butter, SMP, and WMP were the only products produced due to their relative importance to the Irish dairy product portfolio.

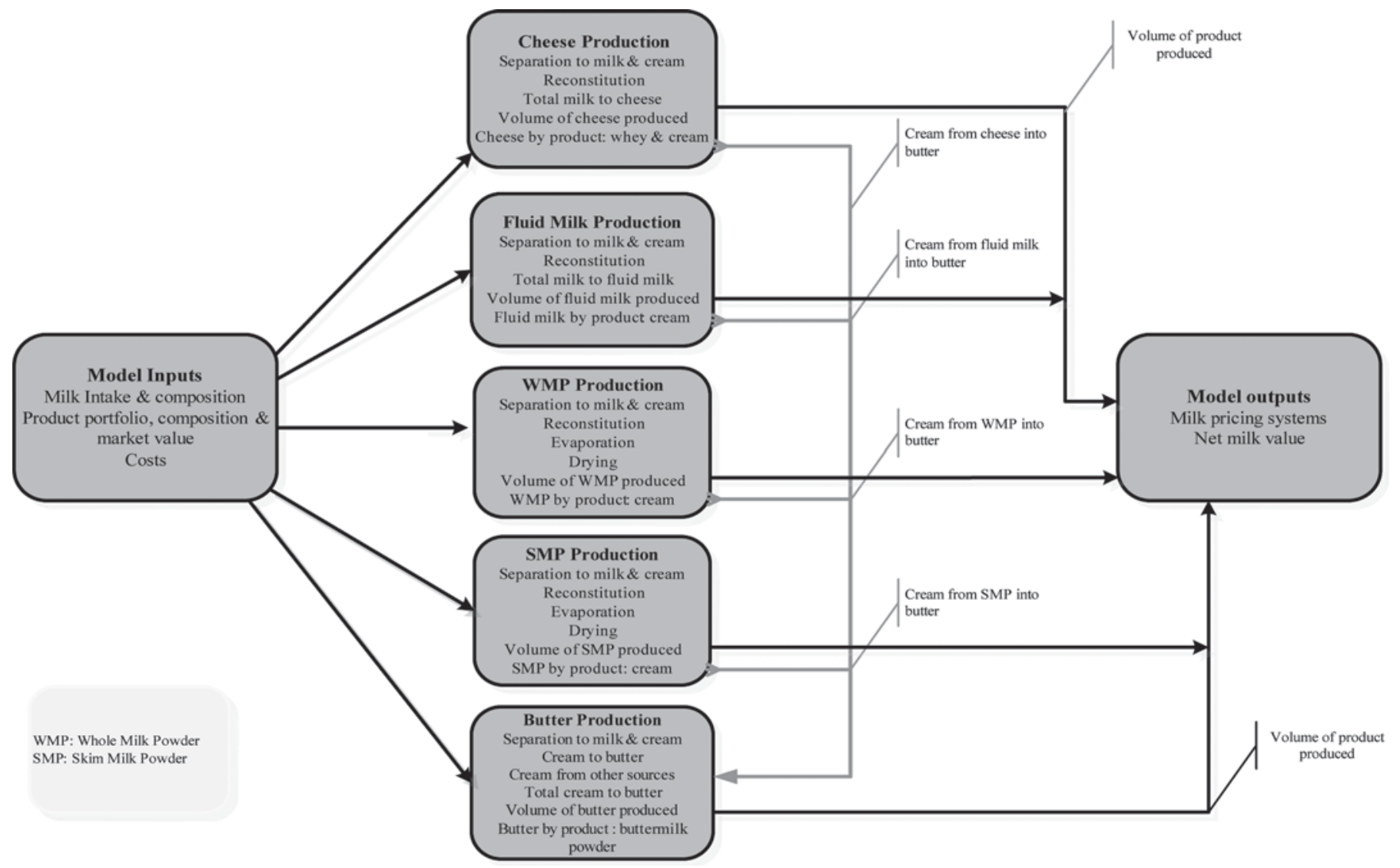

Figure 1. Schematic of dairy processing-sector model. 
Table 2. Market value of the product portfolio per tonne of product ${ }^{1}$

\begin{tabular}{lc}
\hline Product $^{2}$ & $\begin{array}{c}\text { Assumed market } \\
\text { value per tonne, } €\end{array}$ \\
\hline Cheese & $3,291.33^{3}$ \\
Butter & $2,766.33^{3}$ \\
WMP & $2,453.33^{3}$ \\
SMP & $2,017.00^{3}$ \\
Whey powder & $537.67^{3}$ \\
BMP & $2,453.33^{4}$ \\
\hline
\end{tabular}

${ }^{1}$ Assumed 2010 market prices.

${ }^{2} \mathrm{WMP}=$ whole milk powder; $\mathrm{SMP}=$ skim milk powder; $\mathrm{BMP}=$ buttermilk powder.

${ }^{3}$ Productschap Zuivel (2008-2010).

${ }^{4}$ Assumed as per WMP.

\section{Financial Components}

Market Returns. The market values used for the dairy products produced in this model were taken from the Deutsch official quotation (www.prodzuivel.nl) and were representative of a 3-yr average (2008-2010). The market values for butter, WMP, SMP, and whey powder were taken from the international market price for the Netherlands across 2008, 2009, and 2010. The market price for cheese was taken from the same source; however, it was representative of UK cheddar prices because no cheddar price was quoted for the Netherlands. The market price for BMP was assumed equivalent to the market price of WMP. Table 2 presents the product market values used in this analysis.

Processing Costs. The processing costs included in the model are representative of 1999 to 2000 values taken from an Irish processing cost analysis by Breen (2001). Outstanding costs were sourced from published literature, processor annual reports, Integrated Pollution Prevention and Control reports (http://www.epa. ie/terminalfour/ippc/ippc-search.jsp?class-of-activity= Food + and + Drink\&status $=\% 25 \&$ county $=\% 25 \&$ Submi $\mathrm{t}=$ Search + by + Combination), or the Central Statistics Office of Ireland or were assumed based on consultation with experts. All costs were scaled to 2009 values using the industrial price index, wholesale price index, or services producer price index as appropriate. Since the analysis by Breen (2001), technological advancements have contributed to improved productivity. To account for this, labor costs were updated to 2009 values using a productivity-adjusted labor cost index derived from the Census of Industrial Production, processor annual reports, and the Central Statistics Office of Ireland.

The processing costs are split into 2 distinctive groups: volume-related costs and product-related costs. The volume-related costs include milk collection and milk standardization and the volume-related processing costs. The product-related costs include the productrelated processing, storage and packaging, distribution, and marketing costs per tonne.

A rigorous validation of the input data was carried out with processing-sector personnel using the Delphi technique (Dalkey and Helmer, 1963). Table 3 summarizes the processing costs for each product.

Net Value of Milk. The net value, or return, from milk is calculated by multiplying the volume of products produced by their market values less the costs of processing.

$$
\text { net value }=\Sigma\left(\mathrm{VP}_{\mathrm{i}} \times \mathrm{MP}_{\mathrm{i}}\right)-\mathrm{PC}_{\mathrm{i}},
$$

where $\mathrm{VP}_{\mathrm{i}}=$ volume, $\mathrm{MP}_{\mathrm{i}}=$ market price, and $\mathrm{PC}_{\mathrm{i}}=$ processing cost of the ith product.

\section{Component Pricing of Milk}

The objective of an MCP system is to return a price to producers that reflects the yield and value of products produced less the processing costs. The MCP assigns a

Table 3. Volume- and product-related processing costs across the product portfolio ${ }^{1}$

\begin{tabular}{|c|c|c|c|c|c|c|}
\hline Cost & Cheese & Butter & WMP & SMP & $\begin{array}{l}\text { Whey } \\
\text { powder }\end{array}$ & BMP \\
\hline \multicolumn{7}{|l|}{ Volume costs, $€$} \\
\hline Collection $/ \mathrm{L}^{2}$ & 0.0124 & 0.0124 & 0.0124 & 0.0124 & 0.0124 & 0.0124 \\
\hline Standardization/L & 0.0050 & 0.0050 & 0.0050 & 0.0050 & 0.0050 & 0.0050 \\
\hline Processing milk/ $/ \mathrm{L}^{3}$ & 0.0125 & 0.0041 & 0.0099 & 0.0125 & 0.0044 & 0.0099 \\
\hline \multicolumn{7}{|l|}{ Product costs, € } \\
\hline Processing product $/ \mathrm{t}^{3}$ & 125.78 & 98.59 & 176.02 & 173.39 & 251.96 & 176.02 \\
\hline Packaging $/ t^{3}$ & 40.90 & 31.36 & 40.90 & 40.90 & 40.90 & 40.90 \\
\hline Storage $/ \mathrm{t}^{4}$ & 43.47 & 74.10 & 28.28 & 7.85 & 7.85 & 28.28 \\
\hline Distribution $/ \mathrm{t}^{3}$ & 72.04 & 72.04 & 72.04 & 72.04 & 72.04 & 72.04 \\
\hline Marketing costs/t & 50 & 50 & 50 & 50 & 50 & 50 \\
\hline
\end{tabular}

${ }^{1} \mathrm{WMP}=$ whole milk powder; $\mathrm{SMP}=$ skim milk powder; $\mathrm{BMP}=$ buttermilk powder.

${ }^{2}$ Quinlan et al. (2006).

${ }^{3}$ Breen (2001).

${ }^{4}$ Expert consultation. 
Table 4. Milk compositions of the Holstein-Friesian, Jersey, and New Zealand dairy cows

\begin{tabular}{lcrc}
\hline $\begin{array}{l}\text { Milk } \\
\text { component }\end{array}$ & Holstein-Friesian & & \multicolumn{1}{c}{$\begin{array}{c}\text { New } \\
\text { Zealand }^{3}\end{array}$} \\
\hline Fat, \% & 3.83 & 5.33 & 4.39 \\
Protein, \% & 3.34 & 4.06 & 3.65 \\
Lactose, \% & $4.49^{2}$ & 4.53 & 4.67 \\
Minerals, \% & 0.60 & 0.60 & 0.60 \\
Water, \% & 87.74 & 85.48 & 86.69 \\
\hline
\end{tabular}

${ }^{1}$ Central Statistics Office (2009; January-December 2009 data).

${ }^{2}$ Prendiville et al. (2009).

${ }^{3} \mathrm{McCarthy}$ et al. (2007).

value to each component, in this analysis fat and protein, and accounts for the cost of processing each kilogram of milk. The values per kilogram of fat and protein are based on the value of the products produced and the kilograms of fat and protein available for processing. The A + B - C system is an MCP system in which A represents the fat value per kilogram, B represents the protein value per kilogram, and $\mathrm{C}$ represents the carrier and processing cost per kilogram, which will be a negative value. The $\mathrm{C}$ component is calculated in the model as the sum of milk collection costs, standardization costs, and the volume-related cost of processing milk. The $\mathrm{A}$ and $\mathrm{B}$ values are calculated using the marginal rate of technical substitution (MRTS).

\section{Milk Pricing}

The MRTS is used to determine the value per kilogram of fat and protein. The MRTS is the amount by which the quantity of one input, such as protein, can be reduced $\left(-\Delta \mathrm{x}_{2}\right)$ when one extra unit of another input, such as fat, is used $\left(\Delta \mathrm{x}_{1}\right)$ in order that the overall outcome, such as milk value, remains constant.

$$
\operatorname{MRTS}\left(\mathrm{x}_{1}, \mathrm{x}_{2}\right)=\Delta \mathrm{x}_{2} / \Delta \mathrm{x}_{1}=-\mathrm{MP}_{1} / \mathrm{MP}_{2} \text {, }
$$

where $\mathrm{MP}_{1}$ and $\mathrm{MP}_{2}$ are the marginal products of input 1 and input 2, respectively.

For each additional kilogram of fat or protein, the overall milk revenue will be increased depending on product portfolio, product values, and processing costs. The value of that increase is the marginal value of that component. The MRTS uses the calculated net milk value to estimate the values per kilogram of fat and protein, such that when the calculated values of fat and protein are multiplied by the volume of fat and protein in the product portfolio, the result will be equal to the net milk value.

\section{Model Evaluation}

Breed. Milk (1,000 L) with 3 diverse compositions that were representative of (i) typical Irish Holstein-
Friesian (HF), (ii) Jersey (J), and (iii) the New Zealand (NZ) strain of HF, which has different genetic potential for milk production compared with the Irish HF, was simulated in the model. Table 4 summarizes the 3 milk compositions (McCarthy et al., 2007; Central Statistics Office, 2009; Prendiville et al., 2009). This analysis was conducted to examine the effect a variation in milk composition has on the volume of product produced, processing costs, product sale value, component values of milk, and the net value of milk.

The casein content of cow's milk is approximately $80 \%$. Auldist et al. (2004) showed that J milk yielded $10 \%$ more cheese per kilogram than HF milk. In this analysis casein in protein was $80 \%$ for $\mathrm{HF}$ and NZ milk and $81 \%$ for J milk (Cerbulis and Farrell, 1975; Auldist et al., 1998; Auldist et al., 2004).

Scenario Analysis. Two product portfolio scenarios were investigated using the model to demonstrate the change in processing costs, product sale value, component values of milk, and the net value of milk as the Irish product portfolio changed from 2000 to 2008. The product portfolio data were derived from FAOSTAT (2000-2008), which includes cheese, butter, WMP, SMP, whey powder, and evaporated and condensed milk. However, due to the relative importance of cheese, butter, SMP, and WMP to the Irish product mix, whey powder and evaporated and condensed milk were excluded from the total. The percentages for cheese, butter, SMP, and WMP were calculated as a proportion of the cumulative tonnes of cheese, butter, SMP, and WMP produced.

Scenario 1 (S1). The first scenario assumed the Irish product portfolio of 2000 (FAOSTAT, 2000-2008), with $39 \%$ of milk received used in the production of butter, $27 \%$ into cheese, $13 \%$ into WMP, and $21 \%$ into SMP. The by-products of this portfolio are whey and BMP.

Scenario 2 (S2). In the second scenario, the Irish product portfolio of 2008 (FAOSTAT, 2000-2008) was examined, with $30 \%$ of milk received being used to produce butter, $43 \%$ to produce cheese, $14 \%$ to produce WMP, and $13 \%$ to produce SMP. Whey and BMP are by-products of this product portfolio as in $\mathrm{S} 1$.

\section{Sensitivity Analysis}

A $\pm 20 \%$ change to the product market values was used in the sensitivity analysis. The corresponding effect on the model outcomes is reported.

\section{RESULTS}

The results of the analysis are presented below. They are separated into 2 sections based on the 2 product portfolio scenarios analyzed. 
Table 5. Volume of products produced and net milk value and component values of milk from scenario $1^{1}$

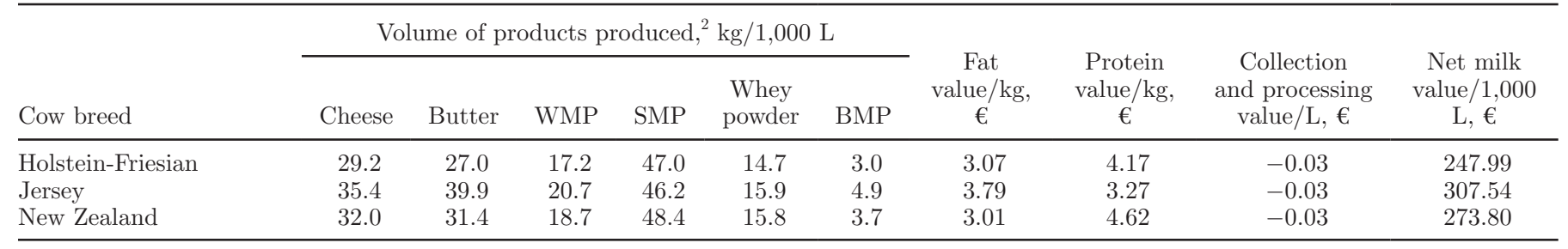

${ }^{1}$ Scenario $1=$ cheese $27 \%$, butter 39\%, SMP 21\%, WMP 13\%. Assumed 2010 market prices.

${ }^{2} \mathrm{WMP}=$ whole milk powder; SMP $=$ skim milk powder; $\mathrm{BMP}=$ buttermilk powder.

\section{S1}

The S1 product portfolio was distributed as follows: $39 \%$ butter, $27 \%$ cheese, $13 \%$ WMP, and $21 \%$ SMP. Presented in Table 5 are the results for S1 across the 3 milk compositions.

Proportion to Separation. To meet final product specification, the model calculated the volume of milk that would have to be separated, based on the composition of the milk and final product. Across the 3 breeds, the proportion to separation for cheese, butter, WMP, and SMP was 0, 100, 8.5, and $97.5 \%$ for HF; 6.0, 100, 21.2 , and $98.2 \%$ for $\mathrm{J}$; and $0,100,13.13$, and $97.6 \%$ for NZ.

Processing Costs and Quantity of Product Produced. The total processing costs, accounting for volume-related and product-related costs, for 1,000 L of HF, J, and NZ milk were $€ 75.30$, €83.62, and $€ 79.33$, respectively. Across the 3 breeds, 1,000 L of milk from $\mathrm{HF}$, J, and NZ cows yielded $29.2,35.4$, and $32.0 \mathrm{~kg}$ of cheese; $27.0,39.9$, and $31.4 \mathrm{~kg}$ of butter; $17.2,20.7$, and $18.7 \mathrm{~kg}$ of WMP; 47.0, 46.2, and $48.4 \mathrm{~kg}$ of SMP; 14.7 , 15.9 , and $15.8 \mathrm{~kg}$ of whey powder; and $3.0,4.9$, and 3.7 $\mathrm{kg}$ of BMP, respectively.

Total Revenue and Net and Component Milk Values. Based on the market values of the product portfolio (Table 2), the total revenue from the volume of products produced for the HF, J, and NZ breeds was $€ 323.29$, €391.15, and €353.13, respectively. The net value of milk, total revenue minus processing costs, for 1,000 L of HF, J, and NZ milk was €247.99, €307.54, and $€ 273.80$, respectively, resulting in a value of approximately 24.8 cents, 30.8 cents, and 27.4 cents per liter, respectively.

The carrier and processing value of -0.03 , rounded up, is the same across each of the cow breeds. For HF, $\mathrm{J}$, and NZ milk, a kilogram of fat was valued at $€ 3.07$, $€ 3.79$, and $€ 3.01$, respectively, with the corresponding values of protein being $€ 4.71$, €3.27, and $€ 4.62$, respectively. The varying values per kilogram of fat and protein across the 3 breeds reflect (i) the different quantity of products that can be produced and (ii) the kilograms of fat and protein available for processing across breeds.

\section{S2}

Presented in Table 6 are the results for S2 (30\% butter, $43 \%$ cheese, $14 \%$ WMP, $13 \%$ SMP) across the 3 cow breeds. The same trends as in the $\mathrm{S} 1$ analysis are repeated here.

Proportion to Separation. The proportion to separation is the same in $\mathrm{S} 2$ as in $\mathrm{S} 1$ because it is dependent on milk composition and product composition, both of which do not change across S1 and S2. The proportion to separation for cheese, butter, WMP, and SMP was $0,100,8.5$, and $97.1 \%$ for HF milk; 6.0, 100, 21.2, and $97.9 \%$ for J milk; and 0, 100, 13.1, and $97.6 \%$ for NZ milk, respectively.

Processing Costs and Quantity of Product Produced. The total processing cost for 1,000 L of milk was $€ 77.20$ for HF milk, €86.41 for J milk, and

Table 6. Volume of products produced and net milk value and component values of milk from scenario $2^{1}$

\begin{tabular}{|c|c|c|c|c|c|c|c|c|c|c|}
\hline \multirow[b]{2}{*}{ Cow breed } & \multicolumn{6}{|c|}{ Volume of products produced, ${ }^{2} \mathrm{~kg} / 1,000 \mathrm{~L}$} & \multirow{2}{*}{$\begin{array}{c}\text { Fat } \\
\text { value } / \mathrm{kg}, \\
€\end{array}$} & \multirow{2}{*}{$\begin{array}{c}\text { Protein } \\
\text { value } / \mathrm{kg}, \\
€\end{array}$} & \multirow{2}{*}{$\begin{array}{c}\text { Collection } \\
\text { and processing } \\
\text { value } / \mathrm{L}, €\end{array}$} & \multirow{2}{*}{$\begin{array}{c}\text { Net milk } \\
\text { value } / 1,000 \\
\text { L, € }\end{array}$} \\
\hline & Cheese & Butter & WMP & SMP & $\begin{array}{c}\text { Whey } \\
\text { powder }\end{array}$ & BMP & & & & \\
\hline Holstein-Friesian & 46.6 & 19.6 & 18.5 & 33.7 & 23.4 & 2.2 & 2.16 & 6.14 & -0.03 & 261.46 \\
\hline Jersey & 56.3 & 30.1 & 22.2 & 33.1 & 25.3 & 3.7 & 3.40 & 4.21 & -0.03 & 326.22 \\
\hline New Zealand & 50.9 & 22.8 & 20.2 & 34.7 & 25.2 & 2.7 & 2.13 & 6.06 & -0.03 & 288.62 \\
\hline
\end{tabular}

${ }^{1}$ Scenario 2 = cheese $43 \%$, butter 30\%, SMP 13\%, WMP 14\%. Assumed 2010 market prices.

${ }^{2} \mathrm{WMP}=$ whole milk powder; $\mathrm{SMP}=$ skim milk powder; $\mathrm{BMP}=$ buttermilk powder. 
$€ 81.55$ for NZ milk. The HF, J, and NZ cows yielded $46.6,56.3$, and $50.9 \mathrm{~kg}$ of cheese; $19.6,30.1$, and $22.8 \mathrm{~kg}$ of butter; $18.5,22.2$, and $20.2 \mathrm{~kg}$ of WMP; 33.7, 33.1, and $34.7 \mathrm{~kg}$ of SMP; 23.4, 25.3, and $25.2 \mathrm{~kg}$ of whey powder; and 2.2, 3.7, and $2.7 \mathrm{~kg}$ of BMP, respectively, from $1,000 \mathrm{~L}$ of milk.

Total Revenue and Net and Component Milk Values. The total revenue of the volume of products produced for the HF, J, and NZ breeds was €338.67, $€ 412.63$, and $€ 370.17$, respectively. The $\mathrm{J}$ milk generated the greatest net milk value at $€ 326.22$ per 1,000 L. The HF milk pool yielded the least net milk value at $€ 261.46$ per 1,000 L. The NZ milk pool generated a net milk value of $€ 288.62$ per $1,000 \mathrm{~L}$.

The carrier and processing value of -0.03 , rounded up, is the same across each of the cow breeds. For HF, $\mathrm{J}$, and NZ milk, a kilogram of fat was valued at $€ 2.16$, $€ 3.40$, and $€ 2.13$, respectively, with the corresponding values of protein per kilogram being €6.14, €4.21, and $€ 6.06$, respectively.

Sensitivity Analysis. In S1 a $20 \%$ reduction in the sale value of cheese, butter, WMP, SMP, whey powder, and BMP resulted in the net milk value for HF, J, and NZ milk falling by 26.1, 25.4, and $25.8 \%$, respectively. Increasing the market value by $20 \%$ raised the net milk values by the same magnitude. Similarly in the $\mathrm{S} 2$ analysis, a $20 \%$ increase or a $20 \%$ decrease in the product market values resulted in a $\pm 25.9,25.3$, and $25.7 \%$ change in the net milk value for $\mathrm{HF}, \mathrm{J}$, and NZ, respectively.

\section{DISCUSSION}

\section{Models}

The US Dairy Sector Simulator developed by Pratt et al. (1997) aims to determine the optimum solution for manufacturing and marketing milk and milk products in the United States. Benseman (1986) also developed a model for the New Zealand dairy industry that was used to determine the most profitable daily production schedule of the various dairy goods being produced. Both of these models have been used as industry decision-support tools and have developed over time, taking into account industry changes as they occur. The model developed here can be used in a similar manner to the United States and New Zealand models whereby the optimal product mix that yields the greatest return can be simulated, taking into account market value, processing cost, and milk composition changes as they occur. The multiple outputs of the model described here of product yields, processing costs, returns, net milk value, and component values of milk all contribute to making this model a very useful tool for the industry.
Papadatos et al. (2002) developed a similar model to that presented here for cheese manufacturing to determine the volume of products produced and the net revenue. In their model they accounted for separation and standardization by removing cream from the milk received, similar to the model presented here. Papadatos et al. (2002) allowed the user to define the products produced, their composition and market value, and the composition and volume of milk received and allowed for the prices of milk resources to be modified. In contrast to the model presented here, Papadatos et al. (2002) did not include manufacturing costs, unless the user incorporated these costs in the product prices. Burke (2006) developed a linear programming model with the objective of minimizing the net cost of producing a quantity of cheese. Similar to the model presented here, Burke (2006) quantified the volume of cheese that could be produced, the net cost, the revenue generated, and processing costs.

A difficulty in developing this processing model was the availability of detailed processor cost data whereby the fixed and variable costs of production could be disaggregated. In this analysis published data from annual reports, Integrated Pollution Prevention and Control reports, and Breen (2001) and consultation with commercial warehousing were used and updated using the most appropriate indices. Ideally real-life processor data would have been used, which would have added value as an Irish-specific processing model and decision-support tool. To overcome this, the processing costs included in the model were rigorously validated via industry consultation.

Milk processing is highly complex with many variables changing throughout the year, for example milk composition, volume of milk, product portfolio, product compositions, and labor requirements. The year-round changes in these and other input variables have not been captured in this model. However, incorporating seasonality, which accurately simulates dairy product production as milk supply, fat and protein compositions, costs, and demand change throughout the year, would enhance the effectiveness of this model, thus making it a more useful, year-round, decision-support tool.

\section{Component Values of Milk}

An important component of the processing-sector model is the multiple component milk pricing system presented in this paper, which makes it a useful tool for the industry. Numerous milk pricing systems have been developed using various methodologies, including linear programming (Bangstra et al., 1988), differential calculus (Ladd and Dunn, 1979), maximum likelihood (Coggins and Hammond, 1994), and MRTS 
(Dillon, 1977). The MRTS methodology used in this analysis calculates the average values per kilogram of fat and protein. This is in contrast to the methodology employed by Breen (2001), which estimated marginal values using shadow prices.

The objective of a milk pricing system is to return a price to producers that reflects the volume and associated market value of products produced from the milk received (Brog, 1971b; Cragle et al., 1986; Emmons et al., 1990). In addition, milk pricing systems can operate as a signal for processors to encourage producers to modify the composition and profile of the milk supply to meet product requirements throughout the year (Brog, 1971a,b).

Multiple component pricing systems can evaluate any number of variables. Hillers et al. (1980) stated that although "lactose is a valuable component in fluid milk and non-fat dry milk, a protein differential is preferable to one utilizing the solids non-fat." Garrick and LopezVillalobos (2000) compared 2 pricing systems: in one, fat and protein had a value, and in the other, lactose also had a value. Their analysis demonstrated that the inclusion of lactose in the payment reduced the values of fat and protein by between 7 and $9 \%$, with the value per kilogram of lactose ranging from $£ 0.22$ to $£ 0.38$ across the portfolios and breeds examined.

\section{Product Portfolio}

As demonstrated in the analysis above, a large component that affects milk returns is the product portfolio. Garrick and Lopez-Villalobos (2000) included standardized fluid milk, butter, cheese, casein, WMP, SMP, whey powder, and BMP in their processing model. They found that milk used to manufacture fluid milk and cheese returned a high value, relative to milk used to produce butter and SMP, which is similar to the findings of many previous models. Papadatos et al. (2002) included a variety of cheeses in their model with liquid whey, whey powder, lactose powder, and whey protein concentrate by-products. They found that as milk composition and prices changed, the optimal resource mix changed, based primarily on the prices of ingredients and final sale values.

The product mix in Ireland is highly reliant on commodity-based products (butter, powder, casein, bulk cheese), accounting for over $60 \%$ of output (Prospectus, 2003). As the world dairy markets open up, Ireland's current product mix will make processors and producers more vulnerable to milk price volatility. As highlighted in the Prospectus Reports (Prospectus, 2003, 2009), diversification of the product portfolio will insulate the Irish dairy industry against this volatility. In 2004 and 2005 , it was estimated that over $44 \%$ of New Zealand's dairy exports were added-value products (New Zealand Dairy Industry, 2010). In Ireland, where over $90 \%$ of dairy produce is exported, the development of valueadded products in addition to the low-cost production of commodity-based products could add value to the Irish dairy market.

\section{Breed}

Cow breed affects each of the components discussed here. As illustrated in the analysis, milk composition has an effect on the product portfolio that can be produced; the component values of milk; and the model outcomes of volumes, costs, and returns.

Garrick and Lopez-Villalobos (2000) also looked at various breeds in their analysis, which included average $\mathrm{NZ}$, Holstein, HF, J, Ayrshire, $\mathrm{J} \times \mathrm{HF}$, and futuristic novel milks, high in solids or protein. They found that when producing a product portfolio with $10 \%$ fluid milk and $90 \%$ cheese or a mix of products, high-solids milk ( $7.02 \%$ fat, $5.30 \%$ protein) had the highest value. However, when producing $70 \%$ fluid milk and $30 \%$ either cheese or cheese and WMP, J milk was the most valuable. These findings were further echoed by Bailey et al. (2005) and Elbehri et al. (1994), who found that J milk yielded better returns relative to HF milk. In addition to the greater fat and protein content of J milk, the greater casein content relative to $\mathrm{HF}$ and $\mathrm{NZ}$ milk also contributes to the greater yield of cheese (Cerbulis and Farrell, 1975; Auldist et al., 1998; Auldist et al., 2004). The MCP system developed in this analysis valued fat per kilogram and protein per kilogram less for J milk than for HF and NZ milk. This is similar to the Garrick and Lopez-Villalobos (2000) analysis, in which they found that the milk pricing systems valued a kilogram of protein from Holstein and HF milk greater than a kilogram of protein from high-solids or $\mathrm{J}$ milk.

Other milk components that can be affected by breed are lactose, whey (Cerbulis and Farrell, 1975), and conjugated linoleic acid, which may become more important as processors move to develop more functional foods. Whether these and other milk components should be included in future milk pricing systems, so that producers are rewarded accordingly or to encourage their production, should be examined. Milk composition attributes could also be included in breeding programs. The Economic Breeding Index in Ireland currently incorporates milk production and fat and protein content, which contributes to over $38 \%$ of the overall index. However, as highlighted in this analysis, the effect other milk components have on product yield and returns to processors and producers indicates that their inclusion in any future indices should be debated. These benefits are in addition to published superiority 
for reproductive performance and feed conversion efficiency. Prendiville et al. (2010) found that across J, $\mathrm{HF}$, and $\mathrm{J} \times \mathrm{HF}$ breeds, $\mathrm{J}$ cows had a greater milk yield and milk composition and they produced more milk solids per unit of body weight and per unit of intake.

In addition to the increased yield benefits of high-solids milk, it also has benefits in terms of fuel and energy efficiency. Milk with low solids inherently has greater water content; therefore, it costs more to transport per liter relative to high-solids milk. Similarly, during processing when water is removed, more energy will be required for the low-solids milk due to its greater water content. Therefore, low-solids milk will be more exposed to volatility in energy costs.

This analysis demonstrates that by increasing the fat and protein content of milk, either through breeding or diet, greater milk returns for producers and processors can be generated. This is an important consideration as the breed profile of the Irish dairy herd changes (for details, see http://www.agriculture.gov.ie/animalhealthwelfare/animalidentificationmovement/cattle/).

\section{CONCLUSIONS}

This analysis illustrates how useful a processing-sector model could be to the Irish dairy processing industry. The model allows for a variation in milk composition to be taken into account to measure the effect on yield, costs, and returns. In addition, the product portfolio can be modified along with the product compositions to estimate the effect of a product portfolio change on the net processing costs, net revenue, and net value of milk. Processing costs can be changed to account for an increase or decrease in the product-related or volumerelated costs. The model presented above is a snapshot of processing activities at a single point in time, with all input figures remaining constant within this time period. In reality milk processing is more complex and changes throughout the year as the milk supply changes. Therefore, this model would be more intuitive for the end user if it modeled milk processing within a year, taking into account the milk supply profile, milk composition, product portfolio, product compositions, product market values, and other components that change throughout the year.

\section{ACKNOWLEDGMENTS}

The authors acknowledge the financial support of the Department of Agriculture, Fisheries and Food (Ireland) through the Research Stimulus Fund.

\section{REFERENCES}

Auldist, M. J., K. A. Johnston, N. J. White, W. P. Fitzsimons, and M. J. Boland. 2004. A comparison of the composition, coagulation characteristics and cheesemaking capacity of milk from Friesian and Jersey dairy cows. J. Dairy Res. 71:51-57.

Auldist, M. J., B. J. Walsh, and N. A. Thomson. 1998. Seasonal and lactational influences on bovine milk composition in New Zealand. J. Dairy Res. 65:401-411.

Bailey, K. W., C. M. Jones, and A. J. Heinrichs. 2005. Economic returns to Holstein and Jersey herds under multiple component pricing. J. Dairy Sci. 88:2269-2280.

Bangstra, B. A., P. J. Berger, A. E. Freeman, R. E. Deiter, and W. S. La Grange. 1988. Economic value of milk components for fluid milk, cheese, butter, and nonfat dry milk and responses to selection. J. Dairy Sci. 71:1789-1798.

Benseman, B. R. 1986. Production planning in the New Zealand dairy industry. J. Oper. Res. Soc. 37:747-754.

Breen, J. 2001. A new direction for the payment of milk: Technology and seasonality considerations in multiple component milk pricing of milk (liquid and manufacturing) for a diversifying dairy industry. MSc Thesis. University College Dublin, Ireland.

Brog, R. A. 1971a. Economic incentives for cheese processors using a protein-fat milk pricing model. J. Dairy Sci. 54:1006-1013.

Brog, R. A. 1971b. Proposed economic formula (model) for deriving the value of cheese milk. J. Dairy Sci. 54:1134-1136.

Burke, J. A. 2006. Two mathematical programming models of cheese manufacture. J. Dairy Sci. 89:799-809.

Central Statistics Office. 2009. Intake of Cows Milk by Creameries and Pasteurisers by Month, Domestic or Import Source and Statistic; Jan-Dec 2009. http://www.cso.ie/px/pxeirestat/Dialog/varval asp? ma $=$ AKM01\&ti $=$ Intake + of + Cows + Milk + by + Creameries + and +Pasteurisers +by+Month,+ Domestic + or + Import+Source +and+Statistic\&path=../Database/Eirestat/Agriculture\%20Milk \%20Production/\&lang=1 Accessed Dec. 11, 2009.

Cerbulis, J., and H. M. Farrell Jr.. 1975. Composition of milks of dairy cattle. 1. Protein, lactose, and fat contents and distribution of protein fraction. J. Dairy Sci. 58:817-827.

Coggins, J. S., and J. W. Hammond. 1994. Component values for milk used in Cheddar cheese. Rev. Agric. Econ. 16:203-213.

Cragle, R. G., M. R. Murphy, S. W. Williams, and J. H. Clark. 1986. Effects of altering milk production and composition by feeding on multiple component milk pricing systems. J. Dairy Sci. 69:282289.

Dalkey, N., and O. Helmer. 1963. An experimental application of the DELPHI method to the use of experts. Manage. Sci. 9:458-467.

Dillon, J. L. 1977. The Analysis of Response in Crop and Livestock Production. 2nd ed. Pergamon Press, Oxford, UK.

Elbehri, A., R. D. Yonkers, S. A. Ford, and S. I. Gripp. 1994. The relative profitability of Jersey versus Holstein farms under alternative milk pricing systems. J. Dairy Sci. 77:1296-1305.

Emmons, D. B., D. Tulloch, and C. A. Ernstrom. 1990. Product-yield pricing system. 1. Technological considerations in multiple-component pricing of milk. J. Dairy Sci. 73:1712-1723.

FAOSTAT. 2000-2009. Agriculture statistics. http://faostat.fao.org/ site/603/DesktopDefault.aspx?PageID=603\#ancor

Garrick, D. J., and N. Lopez-Villalobos. 2000. Potential for economic benefits to the producer from altering the composition of milk. Pages 93-109 in Milk Composition. R. E. Agnew, K. W. Agnew, and A. M. Fearon, eds. British Society of Animal Science, Belfast, Northern Ireland.

Hillers, J. K., V. H. Nielson, A. E. Freeman, J. Dommerholt, and R. E. Deiter. 1980. Value of fat and protein in producer milk. J. Dairy Sci. 63:322-327.

Krell, E., and H. Wietbrauk. 1993. Die Kosten der Modellabeilung Schnittaserei amd Biespiel der Herstellung von Gouda-Kase. Teil Ergebruisseund Intretation der Modellkalkulationen. Kieler Milchwirtshafthiche Forschungsberichte 45:245-271.

Ladd, G. W., and J. R. Dunn. 1979. Estimating values of milk components to a dairy manufacturer. J. Dairy Sci. 62:1705-1712.

McCarthy, S., B. Horan, P. Dillon, P. O'Connor, M. Rath, and L. Shalloo. 2007. Economic comparison of divergent strains of Holstein Friesian cows in various pasture based production systems. J. Dairy Sci. 90:1493-1505. 
New Zealand Dairy Industry. 2010. http://business.newzealand.com/ common/files/Dairy-industry-in-New-Zealand.pdf Accessed May $25,2010$.

Papadatos, A., A. M. Berger, and J. E. Pratt. 2002. A nonlinear optimization model to maximize net revenue in cheese manufacture. J. Dairy Sci. 85:2768-2785.

Pratt J. E., P. Bishop, M. Erba, A. Novakovic, and M. Stephenson. 1997. A Description of the Methods and Data Employed in the U.S. Dairy Sector Simulator. Cornell University, Ithaca, NY.

Prendiville, R., E. Lewis, K. M. Pierce, and F. Buckley. 2010. Comparative grazing behavior of lactating Holstein-Friesian, Jersey, and Jersey $\times$ Holstein-Friesian dairy cows and its association with intake capacity and production efficiency. J. Dairy Sci. 93:764774

Prendiville, R., K. M. Pierce, and F. Buckley. 2009. Comparative production efficiencies: An evaluation of production efficiencies among lactating Holstein-Friesian, Jersey and Jersey $\times$ Holstein-Friesien cows at pasture. J. Dairy Sci. 92:6176-6185.

Productschap Zuivel. 2008-2010. Market price listings. http://www. prodzuivel.nl/Noteringen-Netherland-2010-2009-2008 Accessed June 30,2010
Prospectus. 2003. Strategic Development Plan for the Irish Dairy Processing Sector. PROMAR International, Alexandria, VA.

Prospectus. 2009. The Irish Dairy Industry: Decision Time is Now. PROMAR International, Alexandria, VA.

Quinlan, C., M. Keane, P. Enright, and D. O'Connor. 2006. The milk transport cost implications of alternative dairy factory locations. Agribusiness Discussion Paper No. 47, University College Cork, Ireland.

Van Der Pool, J. 2007. Lessons for an expanding dairy industry: An international perspective. Pages 53-57 in Teagasc Nat. Dairy Conf 2007, Kilkenny, Ireland. Teagasc, Oakpark, Co. Carlow, Ireland.

Van Slyke, L., and W. Price. 1949. Cheese. Orange Judd Publ. Co. Inc., New York, NY.

Wallace, M., J. Breen, and S. Crosse. 2002. Milk pricing revisited: Equity, transparency and producer incentives. Irish Grassland Assoc. Conf., Limerick. 36:106-119. 